\title{
THE CRIMINAL LAW AND THE PRIVATE SECURITY
}

\author{
Aleksandra Deanoska - Trendafilova, PhD \\ Institute of Criminal Law, Faculty of Law "Justinian I" \\ "Ss. Cyril and Methodius"- Skopje \\ E-mail: aleksandra_deanoska@yahoo.com
}

\begin{abstract}
The criminal law and the private security are undoubtedly connected. Namely, the criminal law as a part of the legal science that has accessory dimension protects different individual and collective rights and liberties and other goods and values.

The legally set objective of the private security is "prevention and detection of harmful activities and illegal actions that threaten the physical integrity and dignity of the person and property". This unquestionably implies a connection with some fundamental institutions of the criminal law.

In respect with the criminal substantive law, private security workers need to act within the limits of the provisions of the Criminal Code for the illegality as an element of the offense, the provisions on self-defense and extreme necessity, the foundations and boundaries of the exclusion of illegality, unlawful arrest, the incriminations against violations of life and body, crimes against property, privacy etc.

Some criminal procedural aspects are also relevant to private security primarily the detention within the boundaries set for perpetrators in flagranti.

Another important, yet divergently set segment of this relationship is the possibility of private security workers also to appear in the role of perpetrators of criminal offenses and misdemeanors by exceeding and abusing their powers.

The paper also sets out the main areas of the criminal legislation significant for the private security workers.
\end{abstract}

Key words: criminal law, private security, criminal offence, illegality. 


\section{Introductory remarks}

The Criminal law is one of the fundamental legal disciplines, which have accessory nature, meaning that its subject is aimed at protecting the rights, which are primarily provided and positioned in other legal disciplines and other areas. Thus, criminal law through its incriminations is actually the last method - ultima ratio in protecting the rights, values, interests etc., determined as in family, civil, property law, in the field of economy, health, medicine, security etc.

The establishment of specific offenses tied around one specific object of protection, no matter whether it is a human right, value, phenomenon or concept, challenged the doctrinal phenomenon of "atomized criminal law" - criminal law atomized disciplines. In recent decades, science has seen the emergence and development of, for example, medical criminal law, economic criminal law, cyber-criminal law, organized crime, security law etc.

The aforementioned situation is due to the increased number of criminal offenses with a specific binding point that is not always subject to or at least not a generic object of protection. Therefore, criminal lawyers usually point out that new types of offences arise, for example, computer crimes, which are actually placed and classified in different chapters of the Criminal Code, depending on the central object of protection. Here we face new dilemmas related to issues of systematization, namely, we often stand before the question - whether certain crimes should be moved into a new separate chapter (e.g., computer crimes, crimes of domestic violence, security crimes etc.) or to retain the existing systematic approach.

Regarding the question of the relationship of security (in particular private security) and the criminal law, the situation is even more complex because it does not apply only to the incriminations that link these two variables, but also the general part institutes (self defense, necessity) and procedural law terms (deprivation of liberty) take part in this relation.

\section{The security as a value under criminal law protection}

Given that the criminal law as one of its basic functions has the protection of individual rights and the common functions of life within which the basic legal goods and values are set, the security as one of the fundamental values of human relations is undoubtedly subject to such protection.

The definition of the term security is in itself a complex challenge to resolve. There are various theories about what security constitutes depending on the level of consideration. 


\section{Securiatity}

Moreover, according to some authors, each level sets the security as a separate entity. In this sense, we are talking about individual security, social, state and international security.

In its most extensive meaning, the security is analyzed and its determination is based on several approaches and concepts: structural, realistic, functional and structural functionalist theory of security, dialectical, systematic, formal, idealistic and liberal (i.e. neoliberal) theory and theory of interdependency relations.

A more simplified approach broadly determines the security as an action to prevent accidents and adverse events that primarily takes into account two variables: the volume and value of risk at stake.

With no intention of entering into a broader theoretical explication of the concept of security, we will try to bring it in correlation with the system of criminal law science.

The security (or "safety" as it is often regarded as synonymous in criminal law discourse) is a value that is inseparably linked to the peace, law and order as preconditions for the existence of other legal values that are the focus of legal axiology as part of the philosophy of law. Thus, the link between security and the law, in particular the criminal law is undeniable. The security is not the only value that needs to be provided in the direction of common functions of life, but also the right of each individual in society and above all, it should be provided by the state.

The private security develops more profoundly the last decades as a result of the collapse of the state security systems in certain countries, in the best case, of the inability of states to provide the satisfactory level of protection and security of any legal good of the citizens, regardless whether it is to protect the physical integrity, material goods or the privacy.

Today the development of the private security is thought to have been largely due to the "rebirth of the private property" and the need to provide protection from damage while the determination line between national priorities and private security is reflected in the fact that the prevention of damage dominates in the private security, while the state primarily protects security by ensuring justice in society (through the criminal justice system).

The private security in Macedonia formally started its development with the adoption of the first Law on Protection of Persons and Property in 1999 and in late 2012 followed the adoption of the new Law on Private Security. The private security concept in the Macedonian scientific theory is defined as a necessary activity oriented towards the optimization of security through the prism of strict commercialization, which means providing services through contracts for maintenance of security companies and primarily the protection of people and property. 


\section{Seccurity}

The crossing point of criminal law and private security can be easily noted from the legal definition of private security, which according to the Law on private security, is an activity of public interest aimed at "prevention and detection of harmful occurrences and illegal actions that threaten the physical integrity and dignity of the person and the safety of the property."

The illegality mentioned in the definition is a separate criminal justice institute and legal goods such as bodily integrity, dignity and property enjoy special criminal law protection.

The illegality as institute covered by the definition of private security is a common element of the notion of crime, because as according to article 7 of the Criminal Code, the offense is an unlawful act, stipulated by the law as such and with milestones that are defined by law. In other words, the illegal attack meets the characteristics of a crime and private security entities protect persons and property from committing crimes against them.

Therefore, we can conclude that the Law on private security is a lex specialis for the private security sector, but the powers of the security workers provided with this act are limited within the institutes of criminal law, established in the criminal legislation (certain provisions of the Criminal Code and the Criminal Procedure Code).

\section{At what points do exactly criminal law and private security meet?}

As already noted, the private security workers have legal competences to prevent harmful and illegal actions. Therefore, they provide physical and/or technical security, physical protection, etc.

Some authors emphasize the fact that the general crime, crime against the state and commercial crime dominate among the forms of endangering persons, property and business.

Several examples can illustrate the relationship between both of these areas: criminal law and private security. Thus, for example, cases where the private security worker rejects the attack caused by a person to another one or to a property that has been secured are situations close to the criminal law institute called self-defense. When preventing the harmful effects of natural and other dangers like fire, flood, etc., the private security workers are in situations that in the criminal law are called conditions of extreme necessity. Furthermore, in the exercise of their powers, the private security workers have the right to keep a person deprived of liberty if he/she was caught committing a criminal offense that is prosecuted ex officio. 


\section{Seccurity}

Hence, the workers of private security in the application of their powers and competences may intentionally or unintentionally overstep their authorities and be held criminally liable. Therefore, this implies that the private security workers must keep their actions to permissible limits, within those established by the Law on private security as well as the norms of criminal law.

The relationship between the criminal law and the application of the private security undertakings can be divided into three potential scenarios:

1. Criminal law is a source and complements the bases for the powers and competences of private security workers to ensure that they are placed within the limits set up for the general institutes

of the criminal law.

2. The private security workers directly protect the goods and values already protected by the norms of criminal law through prevention of committing crimes.

3. The private security workersdirectly violate the norms of criminal law and become perpetrators of criminal offences.

The connection of the binding points can be detected in the following potential situations: the physical security with inappropriate use of force by private security worker (or the so - called going over limits of the third person defense as a form of self-defense) that may result in bodily injury, murder, participation in a fight etc. or assault or participation, causing or inciting a fight) or lack of boundaries while protecting assets against attacks on physical integrity; the technical security measures may result in violations of privacy and protection of personal data, where the responsibility is mostly in a form of a misdemeanor and criminal liability may occur in the form of a secret unauthorized disclosure or misuse of personal data.

The by law adopted in order to provide operationalization of certain provisions of the Law in private security - Guidelines on the application of means of force in its provisions obviously respects the restrictions in application of force arising from the criminal law institutions regulated in the Macedonian Criminal Code.

Accordingly, we can conclude that the Guidelines in specific domain even narrow the limits of actions of workers of private security than those existing for the self-defense.Namely, when private security worker performs his/her duty, the attack that is coming should be immediate, meaning direct and an act of endangering life or property. Thus, he/she cannot act on an attack on the honor or reputation of a person. 


\section{Securiaty}

The right to self-defense in line with the Criminal Code of Macedonia belongs to every citizen and it is not limited on these legal goods as for the private security, which is logical because private security is narrowly defined activity with specific targets.

However, what the Guidelines do not elaborate is, for example, the time limit the defense can last to. This of course, does not mean that the private security worker should carry out actions aimed at "defense" when the attack stopped. Criminal law is a "ceiling" for determining the boundaries of the action, so, as it is already mentioned, if the private security worker takes action that would result in bodily injury, for example, after the attack ceased, would be criminally liable.

Problematic issue that arises in this context is whether or what kind and to what extent means of coercion may be applied for "direct unlawful assault aimed at destroying, damaging or disposal of property". Attacks targeting destruction, damage or alienation of property are actually meeting the elements of a certain offense against property (subtraction of objects of other people, damaging items, various forms of theft etc.).

There are different standings in the criminal law theory on this issue. According to some views, the attack on the property allows the defense to, in fact, damage higher legal good (which is present in common law systems).

Most modern legislations, particularly the European ones, belonging to the civil law tradition system make a distinction between an attack on the person and attacks on property, whereas in the second case set stricter restrictive criteria (so, for example, in a case of an attack on property, one has no right to shoot the attacker).

These issues actually affect the institute proportionality partly discussed above. The law requires proportionality through the establishment of the institute excess or excess of self-defense. The requirement for proportionality is primarily addressed to the intensity of the defense that should to be close to the intensity of the attack. Although the law does not require proportionality of the goods, the general principles of criminal law do not allow to an attack on property, for example, responding with infliction of serious bodily injury or death.

Even the practice of the European Court of Human Rights in Strasbourg through its judgments implies the right to life must be accordingly protected.

Another criminal law institute important for private security workers is the extreme necessity, which is also a basis for the exclusion of illegality.

In relation to the legal definition, an act committed in extreme necessity is not considered a crime. Extreme necessity exists when the crime was committed in order the offender to deter from himself or from another, simultaneously happening danger not caused 


\section{Seccurity}

by someone's fault, that otherwise could not be removed, while the evil done is not greater than the evil that has threatened.

As the case is in the self-defense institute, here also exists a special form - due assistance. In fact, generally, any person can put off the danger, which threatens the other, but in this case, there are special categories of persons who are obliged to act in dangerous situations. Examples include firefighters, police officers, doctors etc. In certain cases, this also applies to the private security workers. Art. 10, para. 4 of the Criminal Code of Macedonia stipulate, "There is no extreme necessity if the perpetrator was obligated to expose him to a danger." For example, in case of fire, the firefighter must not take another person's vehicle to escape, but rather should put himself at some risk in order to rescue people. Police officer should also not try to avoid intervention during a fight just because he might be assaulted, because his duty is to expose himself to that danger in order to terminate that situation. The private security workers are also expected to put themselves in danger situation when they are performing their duties since that is the nature of their tasks.

One of the other duties and competences that the private security workers have is the detention of persons, which by nature represents a form of deprivation of liberty. According to article 52 of the Law on private security, the private security worker will detain a person caught committing a criminal offense prosecuted $e x$ officio, and is obliged to immediately inform the police and to act accordingly after receiving an order from the police. This is fully in line with criminal procedural law, according to which "everyone can keep a person that is in flagranticaught committing a crime prosecuted ex officio."

However, because this authorization/competence by its nature enters the sphere of restriction of the rights of others, the exceeding of such authorization constitutes an offense of unlawful deprivation of freedom according to article 140 of the Macedonian Criminal Code. Severe forms of this offence represent the situations where an official with abuse of his /her official position or authority commits the offense.

In other words, a private security worker, for example, has the right to keep a person caught as committing a crime on the guarded property and the respective crime is prosecuted ex officio. However, in opposite case, the employee may be prosecuted for unlawful deprivation of liberty.

Article 158 of the Law on Criminal Procedure, which refers to the grounds and procedure of deprivation of liberty without a court order, determines the longest duration of detention as a time frame even for the police in connection with the detention of the person namely, it must promptly, but no later than six hours from the moment of detention, brought 


\section{Secuurity}

before a competent judge of the pre-trial procedure and to inform the public prosecutor. This provision must be taken into consideration and applied by the private security workers as well.

\section{What kind of criminal law knowledge should private security workers have? Concluding remarks.}

According to the aforementioned, we can define some specific areas related to the question of the criminal law knowledge that private security workers should have.

As far as it comes to the criminal law stricto sensu, every person who deals with the private security activities must have knowledge of the basic principles of criminal law and the elements of the following institutes:

- The concept and characteristics of illegality and the permissive norms of criminal law constituting grounds for exclusion of the illegality; namely, self-defense, extreme necessity, the basis for the exclusion of illegality in the case of a participation in a fight, the objective conditions of incrimination as a basis for distinguishing between the offenses and the misdemeanors.

- The repertoire of offenses where the basic form or the aggravated type has as constitutive element the status of an official of the perpetrator or of the victim.

- The repertoire of criminal offenses against life and body, as well as crimes against property, since the principal aim of the private security as it is stipulated in its legal definition is protecting these legal goods or values.

- The repertoire of the offenses against the freedoms and rights of the citizens and those related to the breaches of the principles of protection of privacy.

- The repertoire of offenses that are prosecuted ex officio, as opposed to cases prosecuted by motion of the damaged party or by motion of the private prosecutor

- The provisions of procedural law relating to the detention of persons when they were found to commit crimes in flagranti, the provisions for recording and storing personal data etc.

- The standards established by the law of the European Court of Human Rights in Strasbourg that apply to areas that are related to this activity.

The correlation between the private security and the criminal law has multidimensional consequence resulting with development of a separate study field as well as a practical dimension. Security services and the criminal justice system essentially have the same goal in protection of specific values and rights in the society. The private security 


\section{Secururity}

workers need not just to gain certain knowledge, but also to develop specific skills in application of their powers and competences in order to give optimal level of protection of the integrity of the persons and protection of property from damages, yet within the legal limits. The legislation that is necessary to be taken into consideration when applying their competences by the security workers covers a number of laws and secondary legislation in different areas of private security, privacy protection, applications of coercive measures and substantive and procedural criminal provisions.

\section{Bibliography}

1. Бакрески, О., Даничиќ, М., Кешетовиќ, Ж., Митевски, С., Приватна безбедност теорија и концепт, Скопје, 2015

2. Ванковска, Б., Бакрески, О., Стојановски, Д., Деаноска-Трендафилова, А., Славески, С., Кузев, С., Герасимоски С., Коментар на Законот за приватно обезбедување, Скопје, 2014

3. Митревска, М., Општествените промени како причина за појавата на приватните безбедносни компании, published in Приватната безбедност во XXI век: состојби и предизвици, Скопје, 2016

4. Деаноска - Трендафилова, А. Приватното обезбедување низ казнено-правна перспектива, published in Приватната безбедност во XXI век: состојби и предизвици, Скопје, 2016

5. Даничић, М., Стајић, Љ., Приватна безбједност, Бања Лука, 2008

6. Камбовски, В., Казнено право - општ дел, Скопје, 2004

7. Камбовски, В., Тупанчески, Н., Казнено право - посебен дел, Скопје 2011

8. Марјановиќ, Ѓ., Каневчев, М., Македонско кривично право - општ дел, Скопје 2010

9. Јанев, И. Поим и дефиниција за безбедноста и теорија на релационизмот во разгледувањето на безбедноста, published in Security dialogues, http://sd.fzf.ukim.edu.mk/no3/543, p.2

10. Roberson, C., Birzer, M.L., Private security - theory meets practice, New Jersey, 2010

11. Vankovska, B., State - building and privatization of security in Macedonia, published in Приватната безбедност во XXI век: состојби и предизвици, Скопје, 2016

12. Sotlar, A., Dvojmoc, M., Private security in Slovenia: 25 years of experiences and challenges for the future, published in Приватната безбедност во XXI век: состојби и предизвици, Скопје, 2016 
13. European Court of Human rights, Judgement in case $S$ and Marper v UK (2008), www.hudoc.echr.int

14. Законот за заштита на личните податоци Службен весник на PM, 6p. 7/2005, $103 / 2008,124 / 2008,124 / 2010,135 / 2011$

15. Закон за обезбедување на лица и имот, Службен весник на РМ 6р. 80/1999

16. Закон за приватно обезбедување, Службен весник на РМ 6р. 166/2012

17. Кривичен законик, Службен весник на Република Македонија“ 6р. 37/1996, 80/1999, 4/2002, 43/2003, 19/2004, 81/2005, 60/2006, 73/2006, 7/2008, 139/2008, 114/2009, 51/2011, 135/2011, 185/2011, 142/2012, 166/2012, 55/2013, 82/2013, 14/2014, 27/2014, 28/2014, 41/2014, 115/2014, 132/2014, 160/2014, $199 / 2014,196 / 2015$ и 226/2015.

18. Закон за кривичната постапка, Службен весник на Р.Македонија бр. 150/2010, $100 / 2012,142 / 2016)$

19. Упатството за начинот на примена на средства на присилба Службен весник на PM, 6p. 86/2013

20. Законот за прекршоците против јавниот ред и мир, Службен весник на РМ, 6p.66/2007 